We should like to record our gratitude to our colleague, Mr G. K. Benson, for histological examination of the gut, and to the Directors of M. Venner and Sons Ltd, Bacon Curers, Reading, for slaughterhouse facilities and helpful co-operation.

\title{
REFERENCES
}

Coates, M. E. (1953). Chem. EF Ind. p. 1333.

Coates, M. E., Davies, M. K. \& Kon, S. K. (1955). Brit. Y. Nutr. 9, 110.

Gordon, H. A. (1952). In $A$ Colloquium 'Studies on the Growth Effect of Antibiotics in Germ-free Animals'. Notre Dame, Indiana: Lobund Institute, University of Notre Dame. (Mimeo.)

Pepper, W. F., Slinger, S. J. \& Motzok, I. (1953). Poult. Sci. 32, 656.

Snedecor, G. W. (1940). Statistical Methods, 3rd ed. Ames, Iowa: Iowa State College Press.

Taylor, J. H. \& Harrington, G. (1955). Nature, Lond., 175, 643.

\section{Influence of Diet on the Acute Toxicity of Hypoglycin-A in Rats}

\author{
By P. C. FENG ANd E. A. KEAN \\ Divisions of Pharmacology and Biochemistry, Department of Physiology, \\ University College of the West Indies, Jamaica, B.W.I.
}

(Received I May 1955)

Hypoglycin-A (Hassall, Reyle \& Feng, 1954), is a toxic polypeptide isolated from the fruit of Blighia sapida-known as the ackee in Jamaica. The toxin produces an acute hypoglycaemia and a depletion of liver glycogen in experimental animals. The fruit is a common dietary item locally, and it has been suspected as one of the causes of 'vomiting sickness', which is an acute syndrome with high mortality usually occurring in Jamaican children with a history of malnutrition (Jordan \& Burrows, 1937; Evans \& Arnold, 1938; Hill, 1952; Jelliffe \& Stuart, 1954). Since dietary deficiency has been suggested as a contributing factor in 'vomiting sickness', the present study was undertaken to examine the relationship between the local diet and the acute toxicity of hypoglycin-A in rats.

\section{EXPERIMENTAL}

Plan of experiment. Three groups of rats were fed respectively on the following diets: (a) a high-carbohydrate, low-protein diet, designated as 'Jamaican diet', comprised mainly of items of vegetable origin commonly consumed by the poorer classes of Jamaicans; $(b)$ the same diet, modified by the replacement of some of the carbohydrate with casein, designated as 'modified Jamaican diet'; and $(c)$ the stock diet, which served as a control. The relative toxicity of hypoglycin-A in the different groups was then compared.

Animals. Albino rats of both sexes from the stock colony were weaned on to the experimental diets at 5 weeks of age, at which time they weighed from 50 to $70 \mathrm{~g}$. Diets, and water with I \% sodium chloride, were fed ad lib. In addition to eighty 
animals used for the toxicity test described below, five rats from the group given the 'Jamaican diet' were killed at the end of the I 2 th week (8th week of dieting) and their livers were removed for glycogen determination by the method of Patrick (1954), and for histological examination.

Diets. The composition of the 'Jamaican diet' and of the 'modified Jamaican diet' is given in Table $\mathrm{r}$. The 'Jamaican diet' was adapted from information compiled by Rhodes (1952). For the 'modified Jamaican diet' brown sugar was replaced by vitamin-free casein. The stock diet was the Purina 'laboratory chow'.

Table I. Percentage composition of diets on the fresh basis

$\begin{array}{lcc}\text { Item } & \begin{array}{c}\text { 'Jamaican } \\ \text { diet' }\end{array} & \begin{array}{c}\text { 'Modified } \\ \text { Jamaican diet' }\end{array} \\ \text { Yellow yam (edible portion) } & 20.0 & 20.0 \\ \text { Green banana (edible portion) } & 30.0 & 30.0 \\ \text { Yellow-maize meal } & 25.0 & 25.0 \\ \text { Sweetened condensed milk } & 12.5 & 12.5 \\ \text { Brown sugar } & 12.5 & 0 \\ \text { Vitamin-free casein" } & 0 & 12.5\end{array}$

* British Drug Houses Ltd.

These diets were prepared as follows: Green bananas and yellow yams were peeled, weighed and cooked within $24 \mathrm{~h}$ of purchase at a market. They were crushed in a hand mill and mixed with the other constituents in the proportions shown. The mixture was partly dried at $200^{\circ} \mathrm{F}$ for about $6 \mathrm{~h}$.

Results of the chemical analyses (Association of Official Agricultural Chemists, I950) of the experimental diets are given in Table 2. Values for the Purina 'laboratory chow' are included for comparison.

No accurate records of food consumption were kept, for the design of the cages did not prevent food wastage. It appeared that all diets were equally acceptable to the animals. Daily consumption was about $6-8 \mathrm{~g} /$ rat.

Table 2. Chemical analysis of diets

( $\mathrm{g} / \mathrm{r} 00 \mathrm{~g}$ diet)

Soluble carbohydrate difference)

'Jamaican'

'Modified Jamaican'

Laboratory chow*

* Values from the pamphlet The Care and Feeding of Laboratory Animals, published by the Ralston Purina Company, St Louis, Mo., U.S.A.

Acute toxicity test. After preliminary screening to locate the approximate lethal dose for each group, the toxicity test was performed on rats when they were ro-I 2 weeks old, i.e. 6-8 weeks after the beginning of experimental feeding, hypoglycin-A dissolved in $0.5-1.0 \mathrm{ml}$. distilled water was injected subcutaneously into the rats. Records of 
death within a $72 \mathrm{~h}$ period following the injection - ' $72 \mathrm{~h}$ mortality rate'-were made. Blood-glucose determinations (Nelson, 1944) were made on twenty-nine rats while they were moribund; all showed severe hypoglycaemia, usually below $20 \mathrm{mg} /$ Ioo ml. blood.

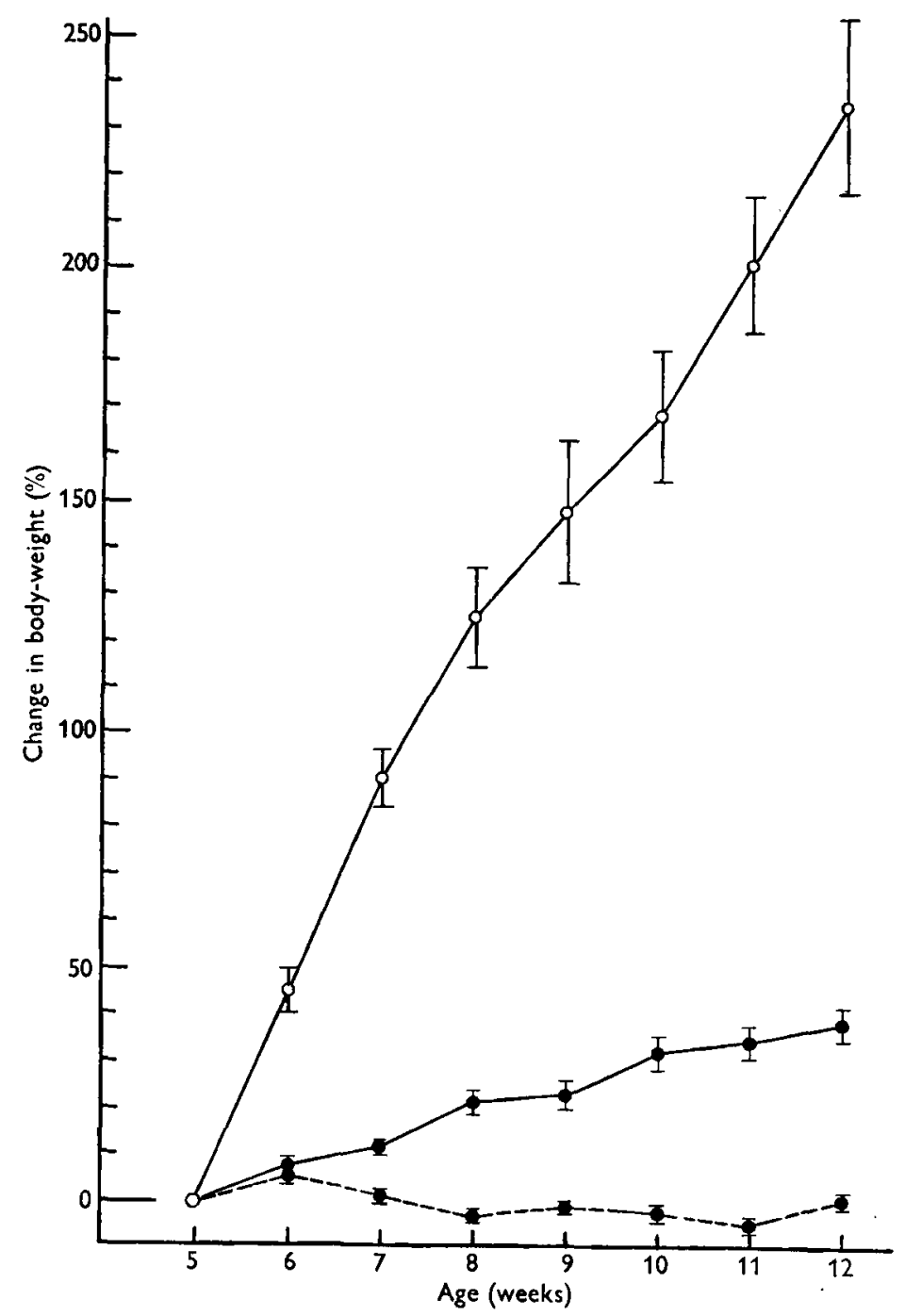

Fig. 1. Effect of diet on the growth of rats. -- - , 'Jamaican diet'; - - , 'modified Jamaican diet'; $O-O$, stock diet; mean values with their standard errors are given, by appropriate modification of these symbols, for groups of eighteen rats.

\section{RESULTS}

Growth of animals. The average change of the body-weight, expressed as a percentage of the weaning weight of the animals on each dietary régime, is plotted against age in Fig. I. There was marked retardation of growth in both the 'Jamaican diet' group and the 'modified Jamaican diet' group. 
Acute toxicity test. In Table 3 is presented the $72 \mathrm{~h}$ mortality rate of animals at various dose levels of hypoglycin-A under the three dietary régimes. The mean bodyweight of the rats at the time of the test is also given. The results showed a definite increase in susceptibility to hypoglycin-A of the rats fed on the 'Jamaican diet' compared to the others.

\section{Table 3. Relation between the toxicity of hypoglycin- $A$ and diet}

\begin{tabular}{|c|c|c|c|c|c|c|}
\hline \multirow[b]{2}{*}{$\begin{array}{c}\text { Hypoglycin-A } \\
\text { dosage } \\
\text { ( } \mu \text { g/g rat) }\end{array}$} & \multicolumn{2}{|c|}{ 'Jamaican diet' } & \multicolumn{2}{|c|}{ 'Modified Jamaican diet' } & \multicolumn{2}{|c|}{ Stock diet } \\
\hline & $\begin{array}{c}\text { Mean } \\
\text { body- } \\
\text { weight (g) }\end{array}$ & $\begin{array}{c}72 \mathrm{~h} \\
\text { mortality } \\
\text { rate* }\end{array}$ & $\begin{array}{c}\text { Mean } \\
\text { body- } \\
\text { weight (g) }\end{array}$ & $\begin{array}{c}72 \mathrm{~h} \\
\text { mortality } \\
\text { rate* }\end{array}$ & $\begin{array}{c}\text { Mean } \\
\text { body- } \\
\text { weight (g) }\end{array}$ & $\begin{array}{c}72 \mathrm{~h} \\
\text { mortality } \\
\text { rate* }\end{array}$ \\
\hline 10 & $65 \cdot 3$ & $0 / 3$ & - & 一 & - & - \\
\hline I5 & $63 \cdot 3$ & $0 / 3$ & - & 一 & - & - \\
\hline 20 & $67 \cdot 0$ & $x / 3$ & - & - & - & - \\
\hline 25 & $57 \cdot 7$ & $0 / 3$ & - & - & - & - \\
\hline 30 & $68 \cdot 3$ & $1 / 3$ & - & - & - & - \\
\hline 35 & $58 \cdot 0$ & $2 / 3$ & 一 & - & - & - \\
\hline 40 & $62 \cdot 7$ & $3 / 3$ & - & - & - & - \\
\hline 45 & $66 \cdot 7$ & $3 / 3$ & - & - & $\rightarrow$ & - \\
\hline 60 & - & - & $8 \mathrm{I} \cdot 0$ & $0 / 3$ & $176 \cdot 3$ & $0 / 3$ \\
\hline 70 & - & 一 & $6 r \cdot 3$ & $0 / 3$ & 184.4 & $0 / 3$ \\
\hline 90 & - & - & $79 \cdot 3$ & $r / 3$ & 19x.7 & $1 / 3$ \\
\hline 110 & - & - & $67 \cdot 3$ & $1 / 3$ & $179 \cdot 0$ & $2 / 3$ \\
\hline 130 & - & 一 & $6 r \cdot 0$ & $2 / 3$ & $172 \cdot 0$ & $3 / 3$ \\
\hline 150 & - & - & $75^{\circ} \circ$ & $3 / 3$ & $182 \cdot 7$ & $3 / 3$ \\
\hline
\end{tabular}

* Denominator represents number of rats tested. Numerator represents number of rats that died within $72 \mathrm{~h}$ of injection.

Glycogen determination and histology on livers. The mean liver-glycogen content of the five rats fed on the 'Jamaican diet' was $7 \cdot x 7 \pm 2 \cdot 23$ (standard error of the mean) $\mathrm{g} / \mathrm{roo} \mathrm{g}$ wet liver. The value appeared to be higher than that of $3-4 \mathrm{~g} / \mathrm{roo} \mathrm{g}$ wet weight found in rats fed on the stock diet (S. J. Patrick, personal communication). Histological examination of the same livers revealed no significant pathological change.

\section{DISCUSSION}

The 'Jamaican diet' was very low in protein and very high in carbohydrate; carbohydrate supplied about $85 \%$ of the available calories. Apart from the apparent deficiency in protein there may have been other imbalances and deficiencies. Calculations from the data of Platt (1945) and Nicholls (1945) reveal that the amounts of riboflavin, calcium and phosphorus in this diet were also below the minimal requirement for rats (Farris \& Griffith, 1949). The rats consuming this diet showed failure of growth and in most instances marked loss of hair without any consistent pattern of the alopecia. No impairment of activity or other gross stigma of dietary deficiency was noted over the experimental period of 8 weeks.

The replacement of some of the carbohydrate of the 'Jamaican diet' with 10\% protein ('modified Jamaican diet') produced very little improvement in the growth of the animals; their growth rate was still markedly retarded when compared with the growth rate of rats fed on the stock diet (see Fig. I). However, the resistance of the 
rats to hypoglycin-A toxicity bore no relation to the growth rate as evidenced by the fact that the lethal dose level for the rats fed on the stock diet was similar to that for rats fed on the 'modified Jamaican diet' (see Table 3). These results exclude the growth rate of the animals as a factor that might have influenced the hypoglycin-A toxicity.

Since the major difference between the 'Jamaican diet' and the 'modified Jamaican diet' lay in the relative amounts of carbohydrate and protein in each, it is suggested that it was the adjustment of the carbohydrate: protein ratio of the 'modified Jamaican diet' that produced the normal response to hypoglycin-A. Further, it appears likely that the absolute amount of protein, rather than of carbohydrate, is of real significance in this connexion.

Patrick (1954) found that hypoglycin-A caused a marked fall in liver glycogen, preceding the fall of blood sugar in rats. He suggested that hypoglycin-A might have caused an exhaustion of liver-glycogen stores which led to the subsequent hypoglycaemia. This suggestion is in agreement with the earlier finding (Hassall et al. 1954) that hypoglycin-A was more toxic to fasting rats, where the liver glycogen must have been low. In the present study, the amount of glycogen in the livers of the rats fed on the 'Jamaican diet' was higher than normal. One might expect that the high liver glycogen would have afforded some protection against the toxicity of hypoglycin-A; yet, in fact, these rats were much more susceptible. The significance of the liverglycogen level is difficult to assess without further investigation.

The importance of other nutrients (vitamins and minerals) that may also influence the toxicity of hypoglycin-A is yet to be elucidated.

\section{SUMMARY}

I. Rats were fed either with (I) a high-carbohydrate, low-protein diet based on dietaries of poorer class Jamaicans, or with (2) diet (I) modified by the replacement of some carbohydrate with 10\% protein, or with (3) a stock diet; the rats were tested for their susceptibility to hypoglycin-A, the toxic polypeptide from the fruit of Blighia sapida.

2. Rats fed on the high-carbohydrate, low-protein diet showed a higher susceptibility than rats fed on the other two diets.

3. It is suggested that the carbohydrate: protein ratio of the diet is a factor which influences the toxicity of hypoglycin-A.

The authors wish to express their gratitude to members of various departments of the University College of the West Indies, namely Dr S. J. Patrick, Division of Biochemistry, Department of Physiology, for the determination of liver glycogen, the Department of Pathology for the histological examinations, and the Department of Chemistry for the supply of hypoglycin-A. This study was partly supported by the Government of Jamaica from a grant for the 'Vomiting Sickness Study'. 


\title{
REFERENCES
}

Association of Official Agricultural Chemists (1950). Official and Tentative Methods of Analysis, 7 th ed. Washington, D.C.: Association of Official Agricultural Chemists.

Evans, K. L. \& Arnold, L. E. (1938). Trans. R. Soc. trop. Med. Hyg. 32, 355.

Farris, E. J. \& Griffith, J. Q. (1949). The Rat in Laboratory Investigation, 2nd ed. Philadelphia: J. B. Lippincott Co.

Hassall, C. H., Reyle, K. \& Feng, P. (1954). Nature, Lond., 173, 356.

Hill, K. R. (1952). W. Indian med. J. 1, 243.

Jelliffe, D. B. \& Stuart, K. L. (1954). Brit. med. F. i, 75.

Jordan, E. O. \& Burrows, W. (1937). Amer. F. Hyg. 25, 520.

Nelson, N. (1944). F. biol. Chem. 153, 375.

Nicholls, L. (1945). Tropical Nutrition and Dietetics, and ed. London: Baillière, Tindall and Cox.

Patrick, S. J. (1954). F. appl. Physiol. 7, 140.

Platt, B. S. (1945). Spec. Rep. Ser. med. Res. Coun., Lond., no. 263.

Rhodes, K. (1952). Brit. F. Nutr. 6, 198.

\section{The Intakes of Essential Amino-acids of Children Who Were Deriving Most of Their Protein from Bread and Vegetables*}

\author{
BY B. P. HUGHES \\ Medical Research Council Department of Experimental Medicine, \\ University of Cambridge \\ (Received I2 May 1955)
}

The recently published studies of Widdowson \& McCance (1954) on the nutritive value of different kinds of bread demonstrated that undernourished children grew rapidly in height and weight and improved in physical condition on diets in which about $60-80 \%$ of the total protein was provided by wheat. Of the remainder of the protein in the diet about $12-2 \mathrm{I} \%$ came from animal sources and $5-15 \%$ from vegetables, chiefly potatoes. The bread was baked from flours of three different extraction rates-100, 85 and $70 \%$-and each flour was found to be equally effective in promoting growth and health.

The children taking part in these investigations, whose ages ranged from 4 to $\mathbf{I}_{5}$ years, lived in two orphanages. At one (Duisburg), wheat provided $75 \%$ of the total calories and the average protein intake was approximately $6 \mathrm{I}-73 \mathrm{~g}$ a day, of which about $8 \mathrm{~g}$ were derived from animal sources. At the other (Vohwinkel), wheat contributed $35 \%$ of the calories and another $35 \%$ were derived from sugar and fat. The total protein intake at this orphanage averaged $5 \mathrm{I}-55 \mathrm{~g}$ a day, of which about $\mathrm{I} \mathrm{g}$ were of animal origin. The Vohwinkel diets were thus appreciably lower in protein, but on account of the additional sugar and fat they were actually some $10 \%$ higher in calories.

The approximate intake of amino-acids provided by these diets has now been calculated and compared with the intake provided by a diet which did not differ greatly

\footnotetext{
* The term 'essential amino-acids' refers to the ten common amino-acids shown to be essential for the normal growth of weanling rats (Rose, Oesterling \& Womack, 1948).
} 